\title{
China's Participation in WTO Negotiations
}

\section{Henry Gao}

\section{OpenEdition \\ Journals}

Electronic version

URL: http://journals.openedition.org/chinaperspectives/5823

DOI: $10.4000 /$ chinaperspectives.5823

ISSN: 1996-4617

\section{Publisher}

Centre d'étude français sur la Chine contemporaine

\section{Printed version}

Date of publication: 30 March 2012

Number of pages: $59-65$

ISSN: 2070-3449

\section{Electronic reference}

Henry Gao, «China's Participation in WTO Negotiations », China Perspectives [Online], 2012/1 | 2012, Online since 23 August 2012, connection on 28 October 2019. URL : http://journals.openedition.org/ chinaperspectives/5823; DOI : 10.4000/chinaperspectives.5823

(C) All rights reserved 


\title{
From the Periphery to the Centre
}

\author{
China's Participation in WTO Negotiations
}

HENRY GAO*

\begin{abstract}
In November 2001, China finally acceded to the World Trade Organization after a marathon accession negotiation that lasted 15 years. As China's accession coincided with the launch of the Doha Round, many commentators predicted that China's participation in the trade negotiations would have significant impacts on the Round. However, this has not proven to be the case. What have been the approaches taken by China in global trade negotiations? Why did China adopt these approaches? How did China's different negotiating approaches affect the dynamics of trade negotiations? These are the questions addressed in this article. The paper argues that China started as a reluctant player in the negotiations, and only gradually made its way into the core decision-making group of the WTO rather late during the round. Even though China has now been accepted as a member of the G-7, the most powerful group in the WTO, it has been playing only supportive rather than leading roles. The article explains the reasons for such low profile approaches, and also examines the value of Chinese proposals from both quantitative and qualitative perspectives. The article concludes with some thoughts on the broader implications of China's growing power in the WTO as a whole.
\end{abstract}

KEYWORDS: China, WTO, Doha Round, Market Access, Trade Negotiation, International Trade, International Law, Accession.

$\mathrm{O}$ 11 November 2001, China finally acceded to the WTO in Doha, Qatar, at the $4^{\text {th }}$ Ministerial Conference, which also launched the first negotiating round of the new trade body since its establishment. As China is the largest country that has ever acceded to the WTO since the formation of the new trade organization, many commentators predicted that its accession would change the dynamics of the negotiations, but they differed in their interpretations on how such change would affect the multilateral trading system. Some viewed this in a more positive light by pointing out that the addition of China would strengthen the developing country bloc and make the WTO a more balanced institution. Others, however, were not so optimistic. Instead, they argued that the Chinese accession would upset the existing power structure of the WTO and make it more difficult to conduct negotiations and reach decisions.

Now in its tenth year of WTO Membership, how has China changed the dynamics in the global trade negotiations? In this paper, I will try to answer this question by reviewing China's record in the Doha Round so far. I will also offer possible explanations to China's choice of particular negotiation approaches, and conclude with some thoughts on China's behaviour in future negotiations.

\section{The silent player}

Joining the WTO at the Ministerial Conference that also launched the new round was both a blessing and curse for China: on the one hand, China was able to participate in the new round as a full member since the very beginning; on the other hand, as a new member, China did not have time to prepare for a more effective participation in the round, which turned out to be not only the biggest, but also the longest and most difficult in the history of the multilateral trading system.

In the beginning phase of the Doha Round, which is also known as the Doha Development Agenda (DDA), China took a rather cautious approach.
While it submitted its first negotiating proposal as early as six months after its accession, most of its earlier years in the WTO were spent observing the negotiations rather than making active interventions. Most of the time, the Chinese delegates would sit quietly in the negotiating room and take notes. On the rare occasion that they took the floor, they usually just recited wordby-word from pre-prepared notes and refrained from interacting with other delegations.

There are several reasons for China's reticence:

\section{The recently-acceded member argument}

Having been under the spotlight for 15 years in one of the longest accession negotiations ${ }^{(1)}$ in the history of the GATT/WTO, the first explanation for China's low profile in public in the DDA is that the Chinese government wanted some quiet breathing space to digest and implement its heavy accession commitments. Indeed, China's concessions on both trade in goods and services greatly exceeded those of other WTO Members, most of which have not changed since the conclusion of the Uruguay Round. For example, Mattoo notes that China's services commitments are generally higher than other WTO Members in terms of both the width of coverage and the depth of market-opening. Indeed, he praises China's commitments under the General Agreement on Trade in Services (CATS) as "the most radical services reform program negotiated

Associate Professor, School of Law, Singapore Management University; Dongfang Scholar Chair Professor, Shanghai Institute of Foreign Trade; LL.M. (University College London); J.D. (Vanderbilt). The author wishes to thank Pierre-Henry de Bruyn and the anonymous reviewer for their most helpful comments. All errors remain the author's own. The author can be reached by email at gaohenry@gmail.com.

1. China's dubious honour of being the WTO Members with the longest accession process has been overtaken by Russia, which finally acceded to the WTO in 2011 after 18 years of accession negotiation. 
in the WTO." (2) This observation is shared by Lardy, who noted in his study of China's accession package that China's commitments "far surpass those made by founding members of the WTO and, in some cases, go beyond those made by countries that have joined the organization since its founding in 1995." (3)

Because of its substantial accession commitments, China has been arguing that it, along with other "Recently Acceded Members (RAMs)," should not be required to make the same level of concessions as the founding WTO Members. ${ }^{\left({ }^{4}\right)}$ As the flip side of this strategy, China also tries to refrain from making aggressive demands in the negotiation and keeps a low profile in general to avoid unwanted attention from the other players.

To be fair, many WTO Members were initially sympathetic to the call for special treatment for RAMs. For this reason, the Hong Kong Ministerial Declaration explicitly stated that "[w]e recognize the special situation of recently-acceded Members who have undertaken extensive market access commitments at the time of accession. This situation will be taken into account in the negotiations." (5) Indeed, had the DDA been concluded according to the original schedule, it is not unlikely that China could have avoided making substantial concessions on agriculture or Non-Agricultural Market Access (NAMA) by hiding under the RAM label.

Unfortunately, however, as the Doha Round drags on, fewer members are willing to give a "free ride" to members such as China that acceded a decade ago. Moreover, the US and EU face increasing pressures: on the one hand, their negotiating partners ask them to make more concessions; on the other hand, vocal domestic constituencies (such as labour and farmer groups) have been calling for their governments to seek more inroads into foreign markets without giving access to their own domestic markets. Thus, they need to find another scapegoat to divert part of the attention. What could be a better target than China - the economic superpower on rapid rise? Thus, starting from 2006, the US and EU have been pushing China from both sides. For example, the US has repeatedly urged China, as the biggest beneficiary of the multilateral trading system, to take more responsibilities at the WTO. ${ }^{(6)}$

Similarly, the EU has argued that China should be required to make contributions just like other WTO Members. ${ }^{(7)}$ While the US and EU use ambiguous terms such as "leadership" to describe such "responsibilities" and "contributions," a careful reading between the lines of their messages reveals that what the US and EU have in mind is really asking China to provide more concessions in key areas such as agriculture, NAMA, and services so that they can have a better report card to show to their domestic stakeholders.

While China fought hard to avoid making new concessions by being recognised as a RAM, it seems that China has lost the battle. According to the latest negotiating drafts, the prevailing consensus seems to be that flexibility will be extended mostly to small, low-income RAMs and "very recently acceded Members," i.e., those that acceded to the WTO after the Doha Round was launched. ${ }^{(8)}$

\section{Lack of expertise}

As a new member, China was not familiar with the rules of game. This is the case for both the substantive rules as well as the procedural rules. Regarding the substantive rules, while most important rules have been compiled in the Secretariat publication entitled The Legal Texts: The Results of the Uruguay Round of Multilateral Trade Negotiations, ${ }^{(9)}$ there are also numerous GATT protocols, decisions, and other legal instruments that are not available in a readily-accessible format. ${ }^{(10)}$ On top of those, as noted by the
Appellate Body in Japan - Alcoholic Beverages II, (11) there are many panel reports adopted during the GATT era, which, as "an important part of the GATT acquis [...] create legitimate expectations among WTO Members, and, therefore, should be taken into account where they are relevant to any dispute." (12) In addition, in line with the tradition of "constructive ambiguity," many WTO rules are drafted in such a way that they are difficult to interpret for any member, let alone newer ones. For new members, it is a major challenge to understand these legal rules.

Compared with the substantive rules, the procedural rules of the WTO are even more difficult for new Members to decipher. While Articles IX and X of the Marrakesh Agreement Establishing the WTO (WTO Agreement) provide a set of elaborate rules for the voting requirements for various decisions, formal voting has been rare in the history of the GATT and WTO. (13) In practice, most if not all decisions are made by "consensus." But what is "consensus"? According to the footnote to Article IX(1) of the WTO Agreement, consensus is defined as the situation where "no Member, present at the meeting when the decision is taken, formally objects to the proposed decision." However, such cryptic explanation offers little help to the uninitiated. Ironically, that is probably the reason why the consensus rule is preferred over the clearly defined and easily understood rules, such as two-thirds or three-fourths majority. To make it even more hopeless, even the consensus rule itself is of little use in reality, as it applies to decisionmaking in formal meetings, which unfortunately is not where most decisions are made at the WTO. As acknowledged by the WTO Secretariat,

[i]mportant breakthroughs are rarely made in formal meetings of [WTO] bodies, least of all in the higher level councils. Since decisions are made by consensus, without voting, informal consultations within the WTO play a vital role in bringing a vastly diverse membership round to an agreement. ${ }^{(14)}$

2. Aaditya Mattoo, "China's Accession to the WTO:The Services Dimension," Journal of International Economic Law, vol. 6, no. 2, 2003, p. 300.

3. Nicholas Lardy, Integrating China into the Global Economy, Brookings, 2002, pp. 104-05.

4. World Trade Organization, Ministerial Conference, 5th Sess., Cancún, Statement by H.E. Mr Lu Fuyuan, Minister of Commerce of China, at 2,WT/MIN(03)/ST/12, 10-14 September 2003.

5. World Trade Organization, Ministerial Declaration of 18 December 2005, at 11,WT/MIN(05)/DEC (2005).

6. See, e.g., US Trade Representative Susan Schwab, Remarks at the 40th Anniversary Gala Dinner of the National Committee on U.S.-China Relations, 12 October 2006, www.ncuscr.org/files/ 2006Gala_SusanSchwab.pdf (consulted on 6 March 2012).

7. See, e.g., Martin Khor, "Trade: China and EU clash over RAMs at NAMA meeting," SUNS, no. 6362, 9 November 2007, www.twnside.org.sg/title2/wto.info/twninfo110719.htm (consulted on 6 March 2012).

8. See, e.g., Section I.A.9, WTO Committee on Agriculture, Revised draft modalities for agriculture, TN/AG/W/4/Rev. 4, 6 December 2008.

9. World Trade Organization, The Legal Texts: The Results of the Uruguay Round of Multilateral Trade Negotiations, Cambridge University Press, 1999.

10. See General Agreement on Tariffs and Trade 1994, Art. 1(a)-(c), 15 April 1994, Marrakesh Agreement Establishing the World Trade Organization, Annex 1, Legal Instruments - Results of the Uruguay Round, 33 I.L.M. 1125 (1994) [hereinafter GATT 1994].

11. Appellate Body Report, Japan - Taxes on Alcoholic Beverages, WT/DS8/AB/R, WT/DS10/AB/R, WT/DS11/AB/R (4 October 1996).

12. Ibid., para 18.

13. For a review of the problems with the GATT/WTO decision-making rules, see Claus-Dieter Ehlermann \& Lothar Ehring, "Are WTO Decision-Making Procedures Adequate for Making, Revising and Implementing Worldwide and 'Plurilateral' Rules?", in Reforming the World Trading System Legitimacy, Efficiency, and Democratic Governance, Oxford University Press, Ernst-Ulrich Petersmann ed., 2005, pp. 497-522.

14. World Trade Organization, "Whose WTO is it anyway?", in Understanding The WTO: The Organization, 104 (2008), www.WTO.org/english/theWTO_e/whatis_e/tif_e/understanding_e.pdf (consulted on 6 March 2012). 
Thus, the only way to acquire essential negotiating skills such as agendasetting and coalition-building is through actual participation in the real work of the WTO.

Unfortunately, as China did not become a formal member until six years after the WTO was formed, it faced a rather steep learning curve. In this regard, the 30 years of experience China had already acquired as a member of the UN at the time it joined the WTO were not of much help for two reasons. First, the nature of trade negotiations is very different from the political grand-standing at the UN. As one WTO official observed: "The UN is a talk-shop; the WTO is for getting real business done." (15) Second, at the UN, China has been a member of its key decision-making body - the Security Council — from the very beginning. In contrast, there is no such formal institutional arrangement at the WTO. Also, the key players in the global trade arena had been rather reluctant to grant China a seat at the table of the informal negotiating groupings for fear of diluting their own power. ${ }^{16)}$ While China has substantial trade volume, this alone has not guaranteed China a position as a key player in WTO negotiations.

Similarly, the 15-year accession negotiation did not teach China much about negotiating as a full member, as the nature of accession negotiation is very different from that of normal negotiations in the WTO. The accession negotiation is a one-way process: while every existing WTO Member can make any request against the acceding member, the acceding member does not have any say on the existing rules of the WTO and has to accept them on a "take it or leave it" basis. In a way, the accession negotiation is easier to handle, as the acceding country only has to worry about its defensive interests. In the normal WTO negotiations, however, each member not only has to look after its defensive interests, but also has to launch offensive requests against other countries. This requires considerable skills in assessing a country's own interests, coordinating positions among various domestic interests groups and different ministries, and formulating and executing its negotiating strategy, all of which China lacked during its early years as a new WTO Member.

\section{The power shift at the WTO}

Since its beginning, the GATT had been largely a trans-Atlantic scheme, where the most important initiatives and decisions were first brokered between the US and EU and then presented to the rest of the membership for acceptance. Later, this arrangement was expanded to include two more countries, i.e., Canada and Japan. Known as "the Quad" among the GATT observers, they controlled the GATT during most of its history.

In the 1980s, things started to change. An early example of this is the strong resistance of the developing countries to the launch of the Uruguay Round. ${ }^{(17)}$ After the conclusion of the Uruguay Round and the establishment of the WTO, the developing countries became even more assertive. Led by India and Brazil, the developing countries fought hard against the launch of a new round, as they believed that they received a bad bargain in the Uruguay Round. The round was only launched in 2001 after the developed countries agreed to make important concessions to developing countries. These include, among others, the official recognition of the "utmost importance" (18) of implementation issues - the central demand of developing countries - in the Doha Declarations, and the adoption of a separate Ministerial Declaration explicitly allowing developing countries the right to grant compulsory licenses to deal with public health crises.

As the negotiations got under way, the power gradually shifted from the Quad to the new G-4, i.e., US, EU, Brazil, and India, and then to the "Five In- terested Parties" (FIPS), i.e., the G-4 plus Australia. This later expanded into the G-6 with Japan back in the picture. However, China, the biggest developing country, had been conspicuously absent from the inner circle. In a way, China behaved liked the proverbial elephant in the room. Notwithstanding its enormous size, it chose to sit quietly in a dark corner, while the other members also largely pretended not to notice its presence.

\section{How could this happen? The reasons are two-fold:}

First, during the early stages of the Doha Round, the negotiations focused mostly on agriculture. This why the FIPS countries were selected, as each had a strong interest in agriculture: the US was eager to open markets abroad while shielding its subsidy programs to its farmers; the EU wished to keep its subsidy program while maintaining the preferential deal it had with its former colonies; Brazil and Australia were highly competitive producers of many agricultural products in the world with strong interests in pushing open foreign markets as leaders of the Cairns Group; while India was most interested in protecting its own vulnerable agriculture sector, the sole livelihood of many of its millions of subsistence farmers. In contrast, China was a net importer of agricultural products, and most of its agriculture products were sold in its huge domestic market. Thus, China did not have a strong interest in the agricultural negotiations.

Second, at least for the first few years after its accession, China was preoccupied with discriminatory clauses tailored-made for China, which it reluctantly accepted as the price for its accession. They can be further divided into two categories: (a) WTO-plus obligations, i.e., obligations that are beyond those normally required of WTO Members; and (b) WTO-minus rights, i.e., rights that are below those generally enjoyed by WTO Members. WTOplus obligations include the obligation to translate all foreign trade laws into one of the official languages of the WTO, a special transitional review mechanism for the first ten years after China's accession, and national treatment to both foreign products and persons. The WTO-minus rights include non-market economy status in antidumping investigations, alternative benchmarks in subsidy and countervailing measures (SCM) investigations, a special textile safeguard mechanism, and a transitional product-specific safeguard mechanism.

As these provisions were specifically designed to soften the impact of China's WTO accession on other members, they have had a much more direct impact on Chinese exports than general WTO rules applicable to other members, at least during the transitional period. While the exact relationship between China's special provisions and the normal WTO rules is still subject to debate, ${ }^{(19)}$ most commentators would agree that the China-specific provisions would take precedence in accordance with the principle of lex specialis derogat legi generali (a special rule prevails over a general rule). Thus, at least until 2017 (before the expiration of these China-specific provisions), China would regard the revision of these special provisions rather than the

15. The author's interview with a senior WTO diplomat (anonymous).

16. As I will note below, due to China's unique position as both a developing country and a major trader, neither the developed countries nor the major developing countries regard China as one of their own, and both view China more as a threat than as a potential ally.

17. See John Croome, Reshaping the World Trading System: A History of the Uruguay Round, Alphen aan den Rijn (Netherlands), Kluwer, 1998, pp. 7-20.

18. Doha Declaration, para. 12

19. For the legal problems raised by these provisions, see Henry Gao, "China's Participation in the WTO: A Lawyer's Perspective," Singapore Year Book of International Law, vol. 11, no. 1, 2007, pp. 54-57. 
revision of the general WTO rules as a more urgent task. Unfortunately, revising the China-specific accession provisions through the WTO negotiations will be extremely hard, if not impossible. To start with, the WTO is illequipped for this task. Among the WTO Agreements, none contains explicit rules on how to revise the accession protocol. In practice, other than a few isolated cases of minor revisions of accession commitments, ${ }^{(20)}$ there has been no precedent of comprehensive revision of accession terms for particular countries. Thus, if China were to insist on revising its accession provisions, the default consensus rule would probably apply. As we have seen from the history of the WTO, consensus among all WTO Members is extremely hard to come by - indeed, it is one of the reasons why the Doha Round is taking so long. More importantly, most other WTO Members are not interested in the idea of revising China's terms of accessions. Furthermore, even assuming that China could somehow persuade other members to accept its request to revise its accession commitments, it probably would have to provide compensation to other members according to the current rules on the renegotiation and modification of schedules. (21) Such compensation would have to take the form of additional concessions to other members beyond the commitments China made upon accession. However, as I explained earlier, it is very unlikely that China would be willing to provide such additional concessions.

Against this context, the recent calls by the US and EC for China to shoulder more responsibility and make more concessions in the Doha Round are a bit ironic: on the one hand, the US and EC imposed these harsh conditions in the accession negotiation and effectively denied China the normal membership status; (22) on the other hand, the US and EC now want China to behave like a normal WTO Member, or better still, to go beyond what normal WTO Members would offer by taking up leadership responsibility. Until the US and EC abandon this double-standard and start to treat China on a nondiscriminatory basis, why should China be expected to contribute to the round above and beyond what is expected of a normal member?

While its interests differ from those of many developing countries, China has decided, for political reasons, to align itself with the developing country camp. Thus, in August 2003, when the major developing country camp, the $\mathrm{G}-20,{ }^{(23)}$ was formed, China quickly jumped on board. While many observers welcomed this as the beginning of China's leadership role among developing countries, they were soon disappointed to find a silent China at the Ministerial Conference in Cancun hiding behind Brazil and India rather than leading other developing countries. One obvious reason is the lack of experience of Chinese diplomats. The less obvious reason, however, is probably more relevant: as with most other groupings in the WTO, the G20 is an issue-specific group. Its main mandate is to pressure developed countries to remove their domestic support and export subsidies on agriculture. However, as one of the largest importers of many agricultural commodities such as wheat, soybean, and cotton, China actually stood to lose out if the developing countries were granted their wish: the removal of subsidies would certainly raise international market prices of these products, and China would have to pay more for its agricultural imports. Thus, China remained silent from the Cancun Ministerial in 2003 through the Hong Kong Ministerial in 2005.

In 2006, things started to change. After resisting the demands of developing countries for a long time, the US and EU started to show more flexibility and moved closer to the targets of developing countries on agricultural issues. For example, the EU finally agreed, during the Hong Kong Ministerial, to eliminate its agricultural subsidies in 2013. At the same time, the US also agreed to cut its trade-distorting farm subsidies from US\$22.5 billion to US\$17 billion per year. (24) Partly encouraged by the progress on agriculture negotiations, partly to shift the blame from themselves to the developing countries, the US and EU started to push for movement in another key area: industrial tariffs (referred as NAMA). This completely turned the table in the negotiations: in agricultural market access negotiations, the developing countries tend to play the offensive role of demandeurs, while the developed countries largely assume the defensive position as demandees. In contrast, in non-agricultural market access negotiations, the developed countries are the demandeurs against developing countries. The reason for this is that developed countries have, due to the five decades of trade negotiations under the GATT, lowered their industrial tariffs to below 5 percent on average, while developing countries have much higher levels of industrial tariffs, usually ranging from 20-30 percent on average.

\section{China on the centre stage}

At the meeting of the G-4 in Potsdam, Germany, in July 2007, the US and EU asked India and Brazil to reduce their tariffs on manufactured goods in exchange for the trans-Atlantic offers on agricultural products. Even though China was not invited to the meeting, all fingers started to point to China this time. For example, according to the Brazilian Foreign Minister Amorim, acceding to the requests presented by the US and EU would risk "deindustrialising Brazil" in key industrial sectors. ${ }^{(25)}$ Instead, he argued that Brazil needed to maintain its right to impose high tariffs on manufactured goods so it would have "policy space for dealing with China." Similarly, Indian Trade Minister Kamal Nath was also reluctant to "pay for someone else's ride," as China stands to reap most of the benefits of lowering industrial tariffs. (26)

While these statements are obviously motivated by self-interest, they have also highlighted the unmistakable truth that China, as the largest exporter of manufactured goods, will gain most from any NAMA package. Therefore, after the Potsdam meeting, the US and EU started to push China

20. For example, when Mongolia acceded to the WTO in 1997, it committed to phase out and eliminate its export duty on raw cashmere within ten years. Due to both economic and environmental concerns, however, Mongolia found itself unable to eliminate the export duty. It asked the Council for Trade in Goods (CTC) for a five-year waiver on its accession commitment on cashmere, which was approved by the CTC on 9 July 2007. WTO, "Goods Council approves waivers for Mongolia, US," WTO: NEWS ITEMS, 9 July 2007, www.wto.org/english/news_e/news07_e/ good_counc_9july07_e.htm (consulted on 6 March 2012). The background of this case can be found in Damedin Tsogtbaatar, "Mongolia's WTO Accession: Expectations and Realities of WTO Membership," in Managing the Challenges of WTO Participation: 45 Case Studies, Cambridge University Press, Peter Gallagher et al. (eds.), 2005, pp. 409-419.

21. See, e.g., GATT 1994, supra note 30, art. XXVIII; General Agreement on Trade in Services, art. XXI, 15 April 1994, Marrakesh Agreement Establishing the World Trade Organization, Annex 1, Legal Instruments - Results of the Uruguay Round, 33 I.L.M. 1125, 1994.

22. As noted by Cattaneo and Braga in their comprehensive study on WTO accessions, while many other WTO Members that acceded to the WTO recently were also asked to assume obligations beyond the normal WTO disciplines, none of them are as onerous as those imposed on China, which remains a "particularly challenging and atypical case." See generally Olivier Cattaneo \& Carols A. Primo Braga, "Everything You Always Wanted to Know about WTO Accession (But Were Afraid to Ask),"World Bank, Policy Research Working Paper Series 5116, 2009.

23. The $\mathrm{G}-20$ is the coalition of developing countries pressing for ambitious reforms of agriculture in developed countries with some flexibility for developing countries (not to be confused with the $\mathrm{G}-20$ group of finance ministers and central bank governors, and its recent summit meetings). It currently has 23 members, i.e., Argentina, Bolivarian Republic of Venezuela, Bolivia, Brazil, Chile, China, Cuba, Ecuador, Egypt, Guatemala, India, Indonesia, Mexico, Nigeria, Pakistan, Paraguay, Peru, Philippines, South Africa, Tanzania, Thailand, Uruguay, and Zimbabwe. See WTO, www.WTO.org/english/tratop_e/agric_e/negoti_groups_e.htm (consulted on 6 March 2012)

24. ICTSD, "G-4 Talks in Potsdam Break Down, Doha Round's Fate in the Balance Once Again," Bridges Weekly Trade News Digest, vol. 11, no. 23, 27 June 2007, http://ictsd.org/i/news/bridgesweekly/ 6515 (consulted on 6 March 2012).

25. Paul Blustein, Misadventures of the Most Favored Nations: Clashing Egos, Inflated Ambitions, and the Great Shambles of the World Trade System, New York, PublicAffairs, 2009, p. 244.

26. Ibid., at p. 245. 
into the centre of the negotiating stage. To carry out their strategy, they employed both "carrots" and "sticks." On the one hand, they argued that China, with its phenomenal growth record, has been the biggest beneficiary of the multilateral trading system. Moreover, China will reap huge gains from a successful Doha Round. Thus, it is in China's self-interest to make more contributions. On the other hand, they kept pressuring China on specific areas. For example, they accused China of providing the largest amount of subsidy among WTO Members to its cotton farmers and asked China to scrap its cotton subsidy. (27) On NAMA, they asked China to lower tariffs in specific sectors that are of interests to the US, such as industrial machinery, chemicals, and electronics. (28)

In summary, they called for China to "take more responsibility" in the multilateral trading system. Such responsibility took the form of the coveted membership in the core decision-making group of the WTO, when China was invited to join the $\mathrm{G} 6$ to form the $\mathrm{G} 7$ at the July 2008 Mini-Ministerial in Geneva.

By then, however, China had become well-versed in the craft of trade negotiations. As noted by Dr. Zhang Xiangcheng, the former Director-General of the Division on WTO Affairs of MOFCOM and current Deputy Permanent Representative of China's WTO mission, it is naive to simply draw its interests along developing country lines. ${ }^{(29)}$ Instead, China should try to form alliances with different countries on an issue-by-issue basis. (30) It is hard to blame China for being selfish, as many other developing countries do not view China as a true friend, either. For example, in anticipation of the expiration of the Agreement on Textile and Clothing (ATC), a group of 47 developing countries led by Mauritius adopted the "Istanbul Declaration" in mid-2004 petitioning the WTO to extend the ATC for another three years. As justification for their request, they cited various alleged "trade distorting practices" by China, which "have allowed China to drop prices for textile and apparel products by as much as 75 percent, and have given China an unassailable and unfair advantage in world markets for textiles and clothing." Thus, unless the ATC were extended, "global textile and clothing trade will be monopolized by a few countries such as China" and this would lead to "massive job disruption and business bankruptcies in dozens of countries dependant upon textile and clothing exports." (31)

Thus, China started to adopt a practical approach to the negotiations. On the one hand, as the largest exporter, China shares many interests with developed countries. One example is trade facilitation. While many developing countries are against the inclusion of the issue, given its position as one of the top exporters in the world, it is actually in China's interest to push for the inclusion of trade facilitation in the WTO framework to make the customs processes of its exporting destinations more efficient and cheaper. On the other hand, as a country with a large low-income population, China also sympathises with the concerns of many developing country members. This is why China supports the demand by India that developing countries should be entitled to a list of special products that will be exempted from tariff cuts, as well as a special safeguard mechanism that can deal with a surge in particular agricultural imports. As a country that straddles the NorthSouth spectrum, China is well positioned to be an "honest broker" among developed and developing countries. In the words of Dr. Zhang, China should play "a balancing, bridging, and constructive role" between developed and developing countries.

One early example of China's bridging role is its proposal at the 2005 Hong Kong Ministerial that the members should try to reap some early harvest of the negotiating results before the conclusion of a comprehensive agreement. This proposal helped to maintain the momentum of negotiations and pushed the negotiation forward. Occasionally, China has even been willing to sacrifice some of its own interests to generate momentum for the round. For example, in 2005, China voluntarily offered to provide dutyfree and quota-free market access to imports from Least Developed Countries (LDC), even though this is not a requirement for developing countries. Of course, playing the bridging role does not necessarily mean that China would always have to sacrifice its interests. While recognising that it has special responsibilities as a large developing country, China resents being singled out in the negotiations. Therefore, China has been consistently opposing efforts by developed countries and some developing countries to differentiate among developing country members. Similarly, when the July 2008 meeting ran into impasse due to India's refusal to give in on special products and a special safeguard mechanism, China turned down the US request for China to provide additional concessions on special products in agriculture and sectoral negotiations on industrial goods. Part of the reason was domestic political difficulties, but an equally important reason was that China did not wish to be treated differently from India, which has rejected US demands on these issues. ${ }^{(32)}$

At the end of the July 2008 meeting, the US started to accuse China of breaking the deal. According to the US, "China wanted a seat at the big kids' table," "They got it, they agreed to the text, and now they are trying to walk that text back." (33) This prompted a rare angry retort from Mr. Sun Zhenyu, the Chinese Ambassador to the WTO:

We have tried very hard to contribute to the success of the round. It is a little bit surprised that at this time the US started this finger pointing. I am surprised because they are now talking about cotton, sugar, rice of China as it seems that we are not going to make any efforts in the Round. Let me explain what China has contributed in the round.

Because of our accession negotiations, our tariff in agriculture on average is $15.2 \%$ and bound at this level, which is lower than the average of European Union, lower than Canada, lower than Japan, lower than quite a number of other developed countries on average. But on that basis, we are committed in this round to cut further down our tariffs - the applied tariffs deeply. And in NAMA, our average tariff rate is 9 , bound at that level. And in this round, we will cut about $30 \%$ in applied level. So we are making contributions of $50 \%$ of the total developing countries in terms of applied rate cut. So that is our contribution.

27. Statement by US Ambassador to the WTO Michael Punke, in ICTSD, Meeting Report: A Decade in the WTO: Implication for China and Global Trade Governance, Geneva, 29 June 2011, available at http://ictsd.org/downloads/2011/07/meeting-report.pdf (consulted on 6 March 2012).

28. ICTSD, "Doha: EU Bid to Break NAMA Sectoral Deadlock Receiving Cool Initial Response," Bridges Weekly Trade News Digest, vol. 15, no. 16, 4 May 2011, available at http://ictsd.org/i/news/ bridgesweekly/105612 (consulted on 6 March 2012).

29. 21st Century Business Herald, "Zhongguo de Duoha celue (China's Doha Strategy)," 30 November 2005, available at http://finance.sina.com.cn/chanjing/b/20051130/09052159265.shtml (consulted on 6 March 2012).

30. Ibid.

31. Istanbul Declaration Regarding Fair Trade in Textiles and Clothing, available at www.ncto.org/quota/ldec.pdf (consulted on 6 March 2012).

32. Paul Blustein, op. cit., pp. 271-273.

33. Ibid., at p. 274. 
If you consider what the contributions that developed countries are going to make, in OTDS the US is spending $\$ 7$ to 8 billion this year or last year, maybe a little bit more to 10 billion, but they are offering $\$ 14.5$ billion with a lot of policy space for themselves. And in their tariff cut in agriculture, they are protecting their sensitivities through sensitive products while they are saying "well even if we have sensitive products for 5 or $4 \%$ of our tariff lines, we will have TRQ expansions". But they can never expand their TRQ to the level of China's TRQ quantities. In our case, our TRQ is 9 million tons for wheat, 7 million tons for corn, 5 million tons for rice. How about your quota, even after the expansion they will never pass half a million tons. Where is the new market access to the developed countries?

In NAMA, they are using erosion trying to cover their sensitivities, keeping their tariff peaks in textiles and garments for another 10 years. They will cover all their sensitivities through various measures while they are asking China to participate in sectors where we have great sensitivities, particularly in chemicals, in electronics, in machinery. ${ }^{(34)}$

\section{The Chinese proposals: Quantity and quality}

Given the substantial obstacles China faced at the beginning, its performance in trade negotiations to date has been quite satisfactory. While no indicator can accurately quantify a country's negotiating prowess, the number of submissions made in the negotiations can serve as a useful proxy. China did not make any submission in the Doha Round until its proposal on fisheries subsidies on 20 June 2002. By February 2005, China had made more than ten submissions. The number further jumped to 67 in December 2007. By the time of the July 2008 meeting, China had made more than 100 submissions. (35) Judging from the rapidly increasing number of submissions, China has been learning very fast.

Measured on the number of proposals submitted, China is one of the most active members of the round. According to a study ${ }^{(36)}$ based on the official records of the WTO in 2003, China made a total of 29 written submissions to the Trade Negotiations Committee and its subsidiary bodies, the Ministerial Conference at Doha, and the working groups on the four Singapore issues, making it the most active developing country participant and the fourth most active among all WTO Members in the Doha Round.

However, numbers alone only tell part of the story. Most of the proposals by China focus on either the procedural issues or the special and differential treatment for developing countries and do not touch on the substance of the negotiations.

One reason for this is China's lack of experience in multilateral trade negotiations, while the other reason is China's awkward position on the substantive issues. As both the largest exporter in the world and a country with millions still struggling on the poverty line, China often finds it hard to define its own interests. For example, along with other developing countries, China has been asking the developed countries to liberalise agricultural trade. At the same time, China also feels the need to protect its highly vulnerable domestic agricultural sector. The only way to protect both interests is through the adoption of a double-standard, which in the WTO is achieved through special and differential treatment provisions for developing countries.

Another example of conflict of interests is in the area of trade remedies, where China is both the biggest victim and a major user. Take antidumping measures for example: as China has been the favourite target of antidumping investigations and actions for many years, we would think that China has an incentive to push for stricter disciplines on antidumping in the Doha Round. On the other hand, as one of the major users of antidumping actions in recent years, it also seems right for China to argue for more discretion to be given to the investigating authorities. Two other factors further complicate the picture: first, as noted by Messerlin, China is much more targeted by developing countries, especially if the number of antidumping actions is adjusted for trade size, i.e., the average number of cases by each country per thousand USD of exports from China to that country. ${ }^{(37)}$ However, as I noted above, it is politically awkward for China to confront developing countries. Second, because China is not treated as a market economy in antidumping investigations, it does not matter much if the general rules under the Antidumping Agreement are improved or not, unless, of course, China argues for clarification of the rules on the treatment of non-market economies in the Antidumping Agreement. But this is going to be a difficult task for two reasons: first, as very few countries are in the non-market economy club, most WTO Members would not be sympathetic to China's request; second, even if the relevant rules in the main Antidumping Agreement were revised, it is unclear whether China would benefit from this at all, as the China-specific provision is regulated by the Accession Protocol, which legally speaking is an entirely different agreement from the Antidumping Agreement.

\section{Concluding thoughts}

As we can see from the analysis above, during its first decade in the WTO, China has gradually moved from the periphery of DDA negotiations to become one of the key players of the round. China did not seek this key player status. Even though it submitted many proposals in the negotiations, it chose to stay out of the spotlight, as it did not wish to shoulder commitments beyond its accession concessions.

However, because of its considerable economic clout and significant trade volume, China was pushed onto centre stage by the other key players. In the view of the author, this move was warranted. As history has shown, no international institutions can survive for long without the support of the key players. As the biggest emerging power in the world today, China deserves a seat at the big-boys' table. On the other hand, granting China a formal role in global trade governance also suits the interests of the other members and the multilateral trading system as a whole: if China were denied the chance to play the game that everyone else has been playing, it might well decide to make its own game, probably to the detriment of other WTO Members. This is a mistake no one can afford to make.

34. Sun Zhenyu, H.E. Ambassador, permanent Mission PRC to the WTO, Statement at the Informal Trade Negotiations Committee Meeting, 11 August 2008, http://wto2.mofcom.gov.cn/aarticle/inbrief/200808/20080805717988.html (consulted on 6 March 2012).

35. Xiangchen Zhang, "Wuzi li de daxiang" (Elephant in the room), China WTO Tribune, Issue 7, 2008, www.WTOguide.net/Html/jsy/06122511161133998087161253268251994.html (consulted on 6 March 2012).

36. Håkan Nordström, "Participation of developing countries in the WTO - New evidence based on the 2003 official records," National Board of Trade, Sweden, 2002, pp. 28-30, www.noits.org/noits06/Final_Pap/Hakan_Nordstrom.pdf (consulted on 6 March 2012).

37. PatrickA. Messerlin, "China in the WTO:Antidumping and Safeguards," in Deepak Bhattasali et al. (eds.), China and the WTO:Accession, policy reform, and poverty reduction strategies, World Bank and Oxford University Press, 2004, p. 32. 
In contrast, those advocating for China to assume the leadership position among developing countries have to be disappointed. To start with, the world today is so different from the world of the 60 s and 70 s, when the line between developed and developing countries was much clearer. Furthermore, due to its unique economic and trade profile, China shares much fewer similarities with the average developing country than with developed countries. Indeed, by some accounts, China has always been the largest economy on earth by accounting for a quarter of the world GDP over the past two millennia. (38) Thus, for China's own interests as well as those of other developing countries, it is probably better for everyone that China be treated as what it is rather than pretending to be a member of the developing country camp. 